\title{
Responsible ownership for cats and dogs from different urban neighborhoods of the City of Umuarama, Paraná, Brazill
}

\author{
Guarda responsável de gatos e cães de diferentes bairros da \\ cidade de Umuarama, Paraná, Brasil
}

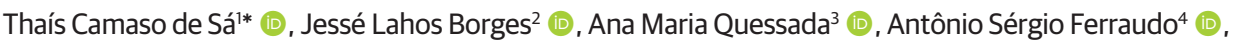
Eduardo Herrera Dias', Marco Aurélio Cunha del Vechio ${ }^{5}$ (D) , Pollyana Linhares Sala ${ }^{6}$ (D), Mayara da Silva Trentim (D) \& Luciana Kazue Otutumi ${ }^{3}$ (D)

'Veterinarian, MSc. Autonomus, Umuarama, PR, Brasil

Veterinarian, MSc. Programa de Pós-graduação em Ciência Animal (PPGCV), Universidade Paranaense - UNIPAR, Umuarama, PR, Brasil

${ }^{3}$ Veterinarian, DSc. PPGCV - UNIPAR, Umuarama, PR, Brasil

${ }^{4}$ Agronomist, DSc. Academic Unit of Setor de engenharia agronômica, Universidade Estadual Paulista "Júlio de Mesquita Filho" - UNESP, Jaboticabal, SP, Brasil

${ }^{5}$ Veterinarian, PPGCV - UNIPAR, Umuarama, PR, Brasil

${ }^{6}$ Veterinarian, DSc. Autonomus, Umuarama, PR, Brasil

\begin{abstract}
The article analyzed the responsible care of dogs and cats of different urban neighborhoods of the City of Umuarama, PR. We interviewed 53 owners by means of a directed questionnaire, obtaining 106 animals evaluated indirectly. It was possible to determine several aspects related to the behavior of owners and important data related to animal welfare, and the deficiency of reproductive control being an important factor verified in this study. It was concluded that the responsible care is not fully exercised by the evaluated population of Umuarama, making urgent the elaboration of public policies to improve this situation.
\end{abstract}

Keywords: pets, neutering, one health, vaccination.

\section{Resumo}

O artigo analisou a guarda responsável e bem-estar de cães e gatos de diferentes bairros urbanos da cidade de Umuarama, PR. Entrevistaram-se 53 tutores por meio de questionário dirigido, obtendo-se 106 animais avaliados indiretamente. Foi possível determinar vários aspectos relacionados ao comportamento dos tutores e dados importantes relacionados ao bem-estar animal, sendo a deficiência do controle reprodutivo um fator importante verificado neste estudo. Concluiu-se que a guarda responsável não é exercida plenamente pela população avaliada de Umuarama, tornando urgente a elaboração de políticas públicas para melhorar tal situação.

Palavras-chave: "pets", castração, saúde única, vacinação.

\section{Introduction}

The animal welfare refers to respect for all forms of life, in order to ensure that they are not treated inhumanely and that no kind of pain or suffering be imputed for them. These conducts promotes the physical and psychological health of animals and allow them to satisfy their needs and natural desires (Bousfiel \& Brown, 2010).

A few years ago, the owners had no great concern in relation to the living conditions of their companion animals. However, currently, these are becoming aware about the fact that animals are sentient beings, i.e., with the ability to feel pain and pleasure (Froehlich, 2017).

The owners are liable to provide appropriate conditions for the maintenance of physical needs, behavioral and psychological of their animals, worrying about their food and veterinary care, among other needs (Tatibana \& Costa-Val, 2009).

The responsible ownership is a set of actions that foster care, respect and responsibility toward animal life (Felipetto et al., 2017). It refers to a condition in which an owner of a pet animal is responsible to meet the animals' needs under his or her ownership. The responsible ownership

\section{BJ $\mathrm{M}$ \\ Brazilian Journal of Veterinary Medicine}

p-ISSN 0100-2430

How to cite: Sá, T. C., Borges, J. L., Quessada, A. M., Ferraudo, A. S., Dias, E. H., del Vechio, M. A. C., Sala, P. L., Trentim, M. S., \& Otutumi, L. K. (2020). RResponsible ownership for cats and dogs from different urban neighborhoods of the City of Umuarama, Paraná, Brazill. Brazilian Journal of Veterinary Medicine, 42, e105420. https://doi.org/10.29374/2527-2179.bjvm105420

Financial support: Coordenação de Aperfeiçoamento de Pessoal de Nível Superior.

Conflict of interests: No conflict of interests declared concerning the publication of this article.

Received: May 24, 2019.

Accepted: October 26, 2019

The study was carried out at Setor de clínica médica de pequenos animais, Universidade Paranaense - UNIPAR, Umuarama, PR, Brasil.

\section{*Correspondence}

Thaís Camaso de Sá

Rua Montes Claros, 1875, Jardim Tamoio CEP 87505-060 - Umuarama (PR), Brasil E-mail: thaiscamaso@outlook.com

Copyright Sá et al. This is an Open Access article distributed under the terms of the Creative Commons Attribution Non-Commercial License which permits unrestricted non-commercial use, distribution, and reproduction in any medium provided the original work is properly cited. 
includes proper diet, veterinary monitoring, neutering, conducting exercises, maintenance of hygiene, providing a suitable and comfortable environment, providing attention, affection, among other cares (Langoni et al., 2011; Almeida et al., 2014).

It is necessary to have awareness of the population and managers of public bodies about the need for programs for the control of animal population, stimulating the responsible ownership (Fernandes et al., 2014). In this way, is possible to act to offer conditions of life consistent with animal welfare, obtaining a healthy interaction between humans and other animals. Such conduct ensures the health, public safety, preservation of the environment, the preservation of the rights of nonhuman animals and the social order (Vieira et al., 2006).

The veterinarian must be alert to cases where there is a possibility of impairment of physical or emotional health of the patient (Rossi et al., 2012; Leal \& Reis, 2017). Stressful events, physical or psychological, are capable of triggering an organic response that causes damage to the organism, especially when these responses persist for a long period of time (Nery et al., 2004; Broom, 2015).

It is an ethical commitment of the owners and veterinarians to preserve the health and welfare of animals, ensuring their physical and mental health. For such purpose, the owner must be committed to all aspects of animal health under his care. The animal health professional must act together, prepared to assess all points of animal welfare, in order to ensure the responsible ownership for companion animals, promoting social well-being and one health (Vieira et al., 2006; Dawson et al., 2016; Hernandez et al., 2018).

The objective of this work was to evaluate the processes related to the acquisition and welfare of dogs and cats from different urban neighborhoods of the city of Umuarama, Paraná, Brazil.

\section{Material and methods}

Considering the number of occupied households in the urban area of Umuarama $(31,295)$ (Instituto Paranaense de Desenvolvimento Econômico e Social, 2017) and the estimate of, respectively, 1.8 and 1.9 cats and dogs, respectively per household (Instituto Brasileiro de Geografia e Estatística, 2013), it was obtained an estimate of 56,331 dogs and 59,460 cats, totaling 115,791 dogs and cats in the city. Considering a sampling error of $10 \%$, it was determined the sample number for completion of questionnaire, according to the formula described in the literature (Barbetta, 1999):

For an $\mathrm{N}=115.791$, the formula was used:

$$
n_{0}=1 E_{0}^{2} \text { and } N=N \cdot n_{0} /\left(N+n_{0}\right)
$$

$\mathrm{N}=$ population size; $\mathrm{E}_{0}=$ tolerated sampling error $=10 \% ; \mathrm{n}_{0}=$ first approximation of the size of the sample; $\mathrm{n}$ = Sample size.

Therefore, the calculation resulted in a sample number of 99.91 animals, which was rounded to 100 .

The study did not include households where no dogs or cats were present, households where guardians declined to participate or did not sign the informed consent form, households whose residents were not present at the time of the visit or in those where the researchers were assisted by minors, totaling 179 absences during the survey.

The owners were from four neighborhoods of Umuarama (PR): Jardim Panorama, Jardim San Martim, Jardim Tamoyo and Jardim San Remo I, chosen by means of simple random sampling using the program Bioestat 5.0 (Ayres et al., 2007). The goal of obtaining data for each neighborhood was 25 dogs or cats, selecting the households to be visited by means of cluster sampling.

The information obtained in each file was processed and analyzed in order to obtain the absolute and relative frequencies. The data were first tabulated on Excel, and then a descriptive analysis of data was carried out, using tools frequency and cross-reference table of the program IBM SPSS version 21.0. The Multiple Correspondence Analysis (MCA) was processed with the Burt Table $X$ ' $X$ where $X$ is the original set of categorical variables and $X^{\prime}$ the transpose of the matrix $X$.

Categorical variables were considered: neighborhood, average household income of owners, animal species, manner of acquisition, which influenced the purchase of the animal form of reproductive control, knowledge of the owners in relation to the benefits of neutering, access 
of animals to the street, deworming and vaccination, average monthly expenditure with the animals of the domicile and habits of veterinary medical consultation.

Multiple Correspondence Analysis uses the basic concept Chi-square test to standardize the frequencies. The pattern of inter-relationship was carried out by residues (difference between the observed and the expected) in a standardized and adjusted manner, i.e., expressed in units of standard deviation. The value of the residue to show dependency among categories must be greater than 1.96 for $\alpha=5 \%$ and greater than 1.60 for $\alpha=10 \%$.

To obtain information on the average household income of the interviewed owners, the classification was performed in accordance with the new methodology established by the Brazilian Association of Research Companies (ABEP) for the classification of socioeconomic classes in 2016 (Associação Brasileira de Empresas de Pesquisa, 2016).

The project was submitted to the Committee for Ethics in Research Involving Human Experimentation, being approved under no. CAAE 68330417.4.0000.0109.

\section{Results and discussion}

In the present study, were interviewed 53 owners of dogs and cats, totalizing 106 animals. Of the 106 animals assessed, 34 (32.08\%) were from the Neighborhood Panorama, 30 (28.30\%) of the Neighborhood Tamoyo, 36 (33.96\%) of Jardim San Remo I and six (5.66\%) of Jardim San Martin. It was found that, of the 53 interviewed owners, 9.43\% (5/53) belonged to class A, 37.74\% (20/53) to class B1 and B2, 39.62\% (21/53) belonged to class C1 and C2 and 5.66\% (3/53) were among classes D and E. Is valid to emphasize that four (7.55\%) owners did not answer to this question.

It was obtained an estimate of 1.5 and 0.5/household dogs and cats respectively, considering that 53 households were evaluated and the number of dogs was $81(76.42 \% ; 81 / 106)$ and the cats 25 (23.58\%; 25/106). This relationship is quite divergent from estimates published by Instituto Brasileiro de Geografia e Estatística (2013), which is 1.8 and 1.9 cats and dogs per household, respectively. This difference may be related to the number of homes and neighborhoods that were assessed, not representing completely the analyzed municipality.

The higher prevalence of dogs $(76.42 \%, 81 / 106)$ in relation to cats $(23.58 \%, 25 / 106)$, also happened in several studies in Brazilian municipalities (Langoni et al., 2011; Catapan et al., 2015; Toscano et al., 2015; Cardoso et al., 2016; Magalhães et al., 2016). This preference can be explained due to the ethological characteristics of canine species, which is seen as more affectionate, vivacious, spontaneous and present when compared to domestic felines (Fuck et al., 2006; Catapan et al., 2015).

In relation to the acquisition of animals, $82.08 \%$ (87/106) of the animals were acquired by adoption or rescue. In a study conducted in the municipality of São Paulo, it was stated that the majority of the dogs were acquired by adoption, as observed in the study here exposed (Canatto et al., 2012). This demonstrates the awareness of the population into host animals, regardless of their racial and aesthetic characteristics. However, this response of the population, in isolation, is still ineffective, since the population of animals that are abandoned is still extremely high in the municipality of Umuarama (Posseti, s/n). Following the example of other studies (Langoni et al., 2011; Canatto et al., 2012; Loss et al., 2012; Silva et al., 2017), it is inferred that there is a need of investment of managers and veterinarians in education and responsible ownership.

The result of the MCA in relation to the acquisition of animals by means of purchase showed correlation between socio-economic category A and the fact that the animals are neutered $(\mathrm{p}<0.05)$. This demonstrates that the owners who acquired their animals by means of purchase were classified in the highest category of income and are concerned with the animal's neutering. This indicates that people with higher education and income are better informed about the breeding of animals (Silva et al., 2014).

When questioned about what influenced the purchase of animals, $77.35 \%(41 / 53)$ of the interviewees reported that it was due to the fact they like animals. This result is similar to the study performed in Teresina, Piauí(BR), in which it was found that $78 \%$ of 100 interviewed owners adopted dogs for the fact they like animals (Quessada et al., 2014). These results demonstrate that the relationship man-pet is beneficial and a source of pleasure (Vaccari \& Almeida, 2007; Faraco \& Seminotti, 2010). The result of this research also showed the development of a very close relationship between the owners and their animals, since that $94.34 \%$ (50/53) of the owners stated 
that they consider the animals as members of the family. Other studies in Brazil demonstrated the same framework (Silva et al., 2009; Silva \& Medeiros, 2014).

In relation to the occurrence of difficulties after the acquisition of animals, 24.53\% (13/53) of the owners reported that they had some kind of difficulty, being the behavioral the main one to (69.23\%; 9/13). Behavior problems affect directly the quality of life of companion animals and the people who live with them. In some countries, the behavior problems are the main causes of abandonment and euthanasia of dogs and cats. This situation can be avoided by means of guidance the owners to seek appropriate treatment when the animal behavior becomes a problem (Soares et al., 2010).

In addition, 77.36\% (41/53) of the owners stated that they spend more than R 50.00 (BRL fifty) per month with their animals, which leads to believe that most of the owners are concerned to ensure the basic care for animals.

It is worth mentioning that $22.64 \%(12 / 53)$ of the owners who claimed to have a monthly average spending less than or equal to fifty BRL ( $\$ 50.00), 3 / 12$ (25\%) have two or more animals in the household, which would be equivalent to an expenditure between twelve and fifty cents BRL (R\$12.50) and twenty five BRL (R \$25.00) per pet. Of course this value does not correspond with the possibility to provide basic care to ensure the health of pets, especially in relation to the nutritional status, since according to the Associação Brasileira da Indústria de Produtos para Animais de Estimação (2016), the average monthly expenditure for the maintenance of dogs is one hundred eighty-one and eighty cents BRL (R\$181.80) and, cats, one hundred and three and twenty four cents BRL (R\$103.24), excepting the costs with vaccines and anthelmintic, since they do not need to be managed on a monthly basis. Therefore, it is observed that, in Umuarama, some owners do not follow the assumptions of animal welfare and responsible ownership, as for instance of what occurs in other cities of Brazil (Cardoso et al., 2016; Silva et al., 2009; Andrade et al., 2015; Panegossi et al., 2016; Machado et al., 2017).

On nutrition, it was found that $57.55 \%$ (61/106) of the animals receive only dog or cat food, $40.57 \%$ (43/106) receive dog or cat food and leftovers of homemade food and 1.89\% (2/106) of the animals receive only leftovers of homemade food. Although the homemade diet can be appropriate for the nutritional needs of animals (Félix et al., 2009) it should be noted that nutritional imbalance, perhaps present in the homemade food, can cause dietary deficiencies with deleterious consequences from the point of view of health (Stockman et al., 2013).

Adequate nutrition is an important factor in animal welfare, since it is through this that the animal meets its basic needs of life maintenance, generating quality of life and longevity to pets (Ogoshi et al., 2015; Peruca, 2017; Teixeira \& Ribeiro, 2017). In addition, the importance of a balanced diet, respecting the level of physical activity of animals and their stage of life, reflects directly on the welfare of the animals (Aptekmann et al., 2013). Many illnesses can be avoided with proper nutrition, being obesity one of the most important problems in companion animals, by becoming a risk factor for many other diseases and decrease the longevity of the animals (Lund et al., 2006; Kopelman, 2000). Thus, it is clear the importance of feed supplied to the animals.

In relation to frequency of animal nutrition, it was found that $83.02 \%$ (88/106) of the animals receive food more than once a day, $16.04 \%$ (17/106) have food available throughout the day and 0.94\% (1/106) of the animals receive food only once a day.

The feed frequency recommended for dogs is at least two daily servings (Ogoshi et al., 2015). Leaving the food always available can generate a selective appetite in animals, as well as attract rats and birds, which can contaminate the food and transmit diseases (Oliveira et al., 2008).

Another important factor in the maintenance of animal welfare and of the responsible ownership refers to surgical sterilization of pets (Langoni et al., 2011). Such conduct prevents the occurrence of random mattings, the birth of unwanted offspring and the abandonment of animals (Vieira et al., 2006). It also prevents the occurrence of disorders such as pyometra and mammary tumors, ensuring quality of life and longevity of the animals (Fonseca \& Daleck, 2000; Root Kustritz, 2012; Magalhães et al., 2016). In the present study it was verified that the majority of animals (71.43\%; 75/105) do not pass through any type of reproductive control. However, $28.57 \%$ (30/105) of the animals are neutered denoting concern on the part of the owners with respect to population control. It should be noted that in relation to this question, one owner abstained from answering it, so the percentage was calculated with 105 animals. 
A signal of concern was the fact that $2.86 \%$ of animals (3/105) receive exogenous hormones as contraception. The administration of such drugs presents serious risks for the animals, causing diseases that can be fatal as pyometra and mammary tumor (Honório et al., 2017).

Still on the reproductive aspect, it was observed that $54.72 \%$ (29/53) of the owners recognize the benefits of neutering and 45.28\% (24/53) are not well informed about it. Other studies in Brazil have shown that the majority of the owners recognize the importance of neutering, although they do not perform it (Loss et al., 2012; Catapan et al., 2015).

Concerning access to the street, it was found that $41.51 \%$ of the animals (44/106) have free access to the street and $58.49 \%(62 / 106)$ does not. This result is similar to a study conducted in a city of São Paulo (Andrade et al., 2015). Allowing the free access of animals to the street represents a failure in the responsible ownership (Catapan et al., 2015). Such conduct generates a lot of problems for society, such as pollution, due to the production of wastes and the scattering of waste; traffic accidents; aggression, both to other non-human animals as humans; mattings, which increase the canine population (Langoni et al., 2011) and the massive predation of native wildlife species, especially birds, by hunting of stray cats (Broom, 2015).

In addition, one should consider that the access of animals to the streets provides one health risk due to the possibility of countless diseases (viral, bacterial and parasitic diseases) that can install themselves in this population, many with zoonotic characteristic (Grossel \& Povaluk, 2016). In addition, free access to street puts the animal at risk of death, both by accidents, such as poisoning and mistreatment (Marlet \& Maiorka, 2010).

Of the 75 animals sexually active, $41.33 \%$ (31/75) have free access to the street, which increases the risk of developing sexually transmitted diseases in this population, as for example, the transmissible venereal tumor and brucellosis in dogs (Amaral et al., 2004; Hollett, 2006; Makloski, 2011). In cats, the fights, especially during periods of mating, put them at risk of catching diseases inoculated in the host through bites and scratches, as for example, the inoculation of feline immunodeficiency virus, or the development of sporotrichosis, and cryptococcosis (Levy et al., 2003; Queiroz et al., 2008; Lloret et al., 2013; Montenegro et al., 2014).

Another important aspect concerns the vaccination and deworming of the companion animals. By means of the deworming gastrointestinal disorders and other illnesses are avoided (Stull et al., 2007). In addition, the occurrence of parasitic zoonoses is prevented, being the genera of greater importance in public health the Ancylostoma spp., implicated in the etiology of cutaneous larva migrans (Siddalingappa et al., 2015; García-Rodrigo et al., 2017) and, probably, in the etiology of sub-acute diffuse unilateral neuroretinitis in humans (Casella et al., 2001). The species Toxocara canis is also important as zoonosis, (being involved in the pathogenesis of the syndrome known as visceral larva migrans (Silva \& Takeda, 2007; Andrade Junior et al., 2015).

Other zoonotic parasitic genera prevalent in Brazil, however, underdiagnosed, include Giardia sp. and Cryptosporidium spp. (Katagiri \& Oliveira-Sequeira, 2007). Thus, the cats and dogs' deworming is one of the acts necessary in the urban environment (Lima et al., 2005). According to information from the owners, $81.13 \%$ (86/106) of the animals of this research are dewormed periodically and $18.87 \%$ (20/106) of them are not dewormed every six or twelve months.

It was found that $73.58 \%$ (78/106) of the animals are vaccinated regularly, $17.92 \%(19 / 106)$ of the animals have delayed vaccines and 8.50\% (9/106) of the animals have never been vaccinated. Vaccination is a prophylactic measure for several viral and bacterial diseases that may affect each species, compromising the animal welfare and which can be fatal or have zoonotic character (Cleaveland et al., 2006; Wang et al., 2007; Shiraishi et al., 2014). The statements regarding the animals deworming and vaccination, could not be proven, since it was not requested the owners the presentation of the animals' card.

It was verified a multiple correspondence between the fact of animals have access to the street with the fact of have never been vaccinated $(\mathrm{p}<0.05)$, demonstrating a problem related to the one health and responsible ownership.

Even as an indicator of responsible ownership, the owners were questioned about the act of taking their animals to veterinary medical consultation, being that $55.8 \%$ of the owners (29/52) reported that only take their animals to the veterinarian when they are sick and 25.0\% (13/52) did not take the animals to consultations. Only ten (19.2\%) animals was taken periodically to the veterinary consultation. In that question, one (1.9\%) owner did not provided the answer, 
totalizing 52 owners evaluated. The fact that a considerable portion of the owners do not bring their animals to the veterinary consultation may be due to the lack of need or on account of financial difficulties (Souza et al., 2002). This can be demonstrated in the result of the MCA, given that, in relation to the socio-economic category of the owners classified as belonging to category D or E or that did not respond to this information, there is a correspondence between access of animals to the street, neutering of animals, no deworming of animals and has never been vaccinated $(\mathrm{p}<0.05)$.

This result demonstrates that despite the owners worry about neutering, even if care is not taken in relation to vaccination, deworming and access of animals to the street, which puts them at risk of developing diseases and demonstrates the lack of financial conditions to the owners can provide animals a better condition of responsible ownership.

On the other hand, the owners classified as belonging to category A had correspondence with the free access of animals to the street, the animals are neutered and attend the veterinarian regularly ( $\mathrm{p}<0.05)$. Through the MCA there was also an association between expenditure less than 10 or between 10 and 13 dollars with the variable not taking the animals to the veterinarian $(\mathrm{p}<0.05)$. These results demonstrate that the owners were classified as belonging to the category A show greater care in relation to the responsible ownership for animals, a fact that has been observed in other studies (Domingues et al., 2015; Silva et al., 2017).

Finally, it was found that $52.83 \%$ (28/53) of the owners informed to stroll with their pets with leash, 24.53\% (13/53) did not have this habit, 11.32\% (6/53) walk with their animals, however, without leash and 11.32\% (6/53) stated that their animals have never had access to the street. Leaving the animal free in the streets is a conduct that does not follow the rules of responsible ownership, which may harm the health only on account of several factors mentioned above.

\section{Conclusions}

It was found that the vast majority of pet acquisition processes among residents of certain urban neighborhoods of the City of Umuarama were carried out through rescue or adoption. However, it was found that responsible ownership is not fully performed by the guardians of such animals, being the most problematic items those related to feeding, reproductive control, veterinary care, vaccination and deworming. These findings were most evident among owners with lower financial income, demonstrating that owners must be prepared, including financially, to acquire a pet. Thus, it is necessary to elaborate public policies that promote projects and campaigns related to responsible ownership, vaccination and neutering of dogs and cats.

\section{Acknowledgements}

Coordenação de Aperfeiçoamento de Pessoal de Nível Superior. (CAPES)

\section{References}

Almeida, J. F., Pedro, D. A., Pereira, V. L. A., Abreu, D. S. C., \& Nascimento, E. R. (2014). Educação humanitária para o bem-estar de animais de companhia. Enciclopédia Biosfera, 10, 1366-1374.

Amaral, A. S., Gaspar, L. F. J., Silva, S. B., \& Rocha, N. S. (2004). Diagnóstico citológico do tumor venéreo transmissível na região de Botucatu, Brasil (estudo descritivo: 1994-2003). Revista Portuguesa de Ciências Veterinárias, 99, 167-171.

Andrade Junior, A. L. F. A., Araújo, K. B. S., \& Medeiros, V. S. (2015). Ocorrência de parasitas com potencial zoonótico em fezes de cães coletadas em vias públicas da cidade de Natal. Revista Humano Ser, 1, 52-59.

Andrade, F. T. M., Araújo, C. L., Paulo, O. L. O. H., Rocha, J. R., Dias, F. G. G., Pereira, L. F., Jorge, A. T., \& Honsho, C. S. (2015). Posse responsável: uma questão multidisciplinar. Acta Veterinaria Brasilica, 9, 91-97. http://dx.doi. org/10.21708/avb.2015.9.1.5359.

Aptekmann, K. P., Mendes-Júnior, A. F., Suhett, W. G., \& Guberman, U. C. (2013). Manejo nutricional de cães e gatos domiciliados no estado do Espírito Santo - Brasil. Arquivo Brasileiro de Medicina Veterinária e Zootecnia 65(2), 455-459. http://dx.doi.org/10.1590/S0102-09352013000200022.

Associação Brasileira da Indústria de Produtos para Animais de Estimação - ABINPET. (2016). ABINPET informa custo médio mensal de manutenção de animais de estimação. Retrieved in 2018, March 15, from http://abinpet. org.br/site/abinpet-informa-custo-medio-mensal-de-manutencao-de-animais-de-estimacao/

Associação Brasileira de Empresas de Pesquisa-ABEP.(2016). Critério de classificação econômica Brasil. Retrieved in 2018, December 5, from ww.abep.org/criterio-brasil 
Ayres, M., Ayres, M. J., Ayres, D. L., \& Santos, A. (2007). BioEstat 5.0: aplicações estatísticas nas áreas das ciências biológicas e médicas. Belém: Sociedade Civil Mamirauá.

Barbetta, P. A. (1999). Estatística aplicada às ciências sociais (3. ed.). Florianópolis: UFSC.

Bousfiel, B., \& Brown, R. 2010. What is Animal welfare. Veterinary Bulletin. Retrieved in 2016, February 15, from https://www.afcd.gov.hk/tc_chI/quarantine/qua_vb/files/AW8.pdf

Broom, D. M. (2015). New research relevant to companion animal welfare. Companion Animal, 20(10), 548-551. http://dx.doi.org/10.12968/coan.2015.20.10.548.

Canatto, B. D., Silva, E. A., Bernardi, F., Mendes, M. C. N. C., Paranhos, N. T., \& Dias, R. A. (2012). Caracterização demográfica das populações de cães e gatos supervisionados do município de São Paulo. Arquivo Brasileiro de Medicina Veterinária e Zootecnia, 64(6), 1515-1523. http://dx.doi.org/10.1590/S0102-09352012000600017.

Cardoso, D. P., Oliveira, R. P., Estrela, D. S., Saraiva, L. A., Farias, M. P. O., \& Silva, P. O. (2016). Perfil dos tutores de cão e gato no município de Bom Jesus-PI. Pubvet,10(8), 580-635. http://dx.doi.org/10.22256/pubvet.v10n8.580-586.

Casella, A. M. B., Machado, R. A., Tsuro, A., Hato, M., Costa, R., \& Farah, M. E. (2001). Seria o Ancylostoma caninum um dos agentes da neurorretinite sub-aguda difusa unilateral (D.U.S.N) no Brasil? Arquivos Brasileiros de Oftalmologia, 64(5), 473-476. http://dx.doi.org/10.1590/S0004-27492001000500019.

Catapan, D. C., Villanova Junior, J. A., Weber, S. H., Mangrich, R. M. V., Szczypkovski, A. D., Catapan, A., \& Pimpão, C. T. (2015). Percepção e atitudes do ser humano sobre guarda responsável, zoonoses, controle populacional e cães em vias públicas. Revista Brasileira de Ciência Veterinária, 22(2), 92-98. http://dx.doi.org/10.4322/rbcv.2015.358.

Cleaveland, S., Kaare, M., Knobel, D., \& Laurenson, M. K. (2006). Canine vaccination-providing broader benefits for disease control. Veterinary Microbiology, 117(1), 43-50. http://dx.doi.org/10.1016/j.vetmic.2006.04.009. PMid:16701966.

Dawson, L. C., Dewey, C. E., Stone, E. A., Guerin, M. T., \& Niel, L. (2016). A survey of animal welfare experts and practicing veterinarians to identify and explore key factors thought to influence canine and feline welfare in relation to veterinary care. Animal Welfare, 25(1), 125-134. http://dx.doi.org/10.7120/09627286.25.1.125.

Domingues, L. R., César, J. A., Fassa, A. C. G., \& Domingues, M. R. (2015). Guarda responsável de animais de estimação na área urbana do município de Pelotas, RS, Brasil. Ciência \& Saúde Coletiva, 20(1), 185-192. http:// dx.doi.org/10.1590/1413-81232014201.19632013. PMid:25650612.

Faraco, C. B., \& Seminotti, N. (2010). Sistema Social humano-cão a partir da autopoiese em Maturana. PSICO, 41, 310-316.

Felipetto, L. G., Sangioni, L. A., Krause, A., Souza, J. C. M., \& Chagas, J. C. (2017). Saúde pública e guarda responsável de animais domésticos nas escolas do município de Santa Maria, estado do Rio Grande do Sul, Brasil: Projeto Amigo do Animal. Revista de Educação Continuada em Medicina Veterinária e Zootecnia do CRMV-SP, 15, $92-93$.

Félix, A. P., Sá-Fortes, C. M. L., Silva, A. C. M., Nascimento, S. T., Carciofi, A. C., Laurentiz, A. C., \& Bergamaschine, A. F. (2009). Digestibilidade de uma dieta caseira e dois alimentos comerciais, econômico e super-prêmio, para cães. Archives of Veterinary Science, 14(1), 25-30. http://dx.doi.org/10.5380/avs.v14i1.13228.

Fernandes, T. R., Corrêa, A. G., Pereira, C. H. C., Garrido, L. L., Coppieters, C. C., \& Manhoso, F. F. B. (2014). Ações públicas no controle populacional e posse responsável de cães e gatos aplicadas no município de Marília/ SP no período de 2008 a 2011. Revista Unimar Ciências, 23, 23-28.

Fonseca, C. S., \& Daleck, C. R. (2000). Neoplasias mamárias em cadelas: influência hormonal e efeitos da ovário-histerectomia como terapia adjuvante. Ciência Rural, 30(4), 731-735. http://dx.doi.org/10.1590/ s0103-84782000000400030.

Froehlich, G. (2017). As regulações jurídicas de bem-estar animal: senciência, produtividade e os direitos dos animais. Revista de Antropologia, 1, 34-47.

Fuck, E. J., Fuck, E. T., Delarissa, F., \& Curti, C. E. (2006). Relação homem × animal: aspectos psicológicos e comportamentais. Revista Nosso Clínico, 9(49), 46-58.

García Rodrigo, C. G., Tous Romero, F., \& Zarco Olivo, C. (2017). Cutaneous larva migrans, welcome to a warmer Europe. Journal of the European Academy of Dermatology and Venereology, 31(1), e33-e35. http://dx.doi. org/10.1111/jdv.13621. PMid:27004620.

Grossel, L. A., \& Povaluk, M. (2016). Medidas profiláticas para amenizar a questão das zoonoses ocasionadas por cães abandonados nas ruas do bairro Faxinal, Mafra-SC. Saúde \& Meio Ambiente, 5(2), 3-20. http://dx.doi. org/10.24302/sma.v5i2.888.

Hernandez, E., Fawcett, A., Brouwer, E., Rau, J., \& Turner, P. V. (2018). Speaking up: veterinary ethical responsibilities and animal welfare issues in everyday practice. Animals, 8(1), 15. http://dx.doi.org/10.3390/ani8010015. PMid:29361786.

Hollett, R. B. (2006). Canine brucellosis: outbreaks and compliance. Theriogenology, 66(3), 575-587. http://dx.doi. org/10.1016/j.theriogenology.2006.04.011. PMid:16716382.

Honório, T. G. A. F., Fonseca, A. P. B., Araújo, E. K. D., Moura, V. M., Chaves, R. A. A., Rodrigues, M. C., \& Klein, R. P. (2017). Implicações patológicas após o uso de anticoncepcional, em cadelas situadas em Teresina - PI. Pubvet, 11(2), 176-180. http://dx.doi.org/10.22256/pubvet.v11n2.176-180.

Instituto Brasileiro de Geografia e Estatística - IBGE. (2013). Pesquisa Nacional de Saúde. Retrieved in 2017, July 4, from https://biblioteca.ibge.gov.br/visualizacao/livros/liv94074.pdf 
Instituto Paranaense de Desenvolvimento Econômico e Social - IPARDES. (2017). Caderno estatístico município de Umuarama. Retrieved in 2017, May 25, from http://www.ipardes.gov.br/index.php?pg_conteudo=1\&cod_conteudo=30

Katagiri, S., \& Oliveira-Sequeira, T. C. G. (2007).Zoonoses causadas por parasitas intestinais de cães e o problema do diagnóstico. Arquivo Instituto Biológico, 74, 175-184.

Kopelman, P. G. (2000). Obesity as a medical problem. Nature, 404(6778), 635-643. http://dx.doi.org/10.1038/35007508. PMid:10766250.

Langoni, H., Troncareli, M. Z., Rodrigues, E. C., Nunes, H. R. C., Harumi, V., Henrique, M. V., Silva, K. M., \& Shimono, J. Y.(2011). Conhecimento da população de Botucatu-SP sobre guarda responsável de cães e gatos. Veterinária e Zootecnia, 18, 297-305.

Leal, M. A. C., \& Reis, S. T. J. (2017). Teoria do link e o papel do médico veterinário no diagnóstico de maus-tratos. Revista Uningá, 51, 106-109.

Levy, J. K., Snyder, P. S., Taveres, L. M., Hooks, J. L., Pegelow, M. J., Slater, M. R., Hughes, K. L., \& Salute, M. E. (2003) Prevalence and risk factors for heartworm infection in cats from northern Florida. Journal of the American Animal Hospital Association, 39(6), 533-537. http://dx.doi.org/10.5326/0390533. PMid:14736717.

Lima, J. L., Andrade, L. D., Aguiar-Santos, A. M., Alves, L. C., \& Medeiros, Z. (2005). Contaminação por ovos de Toxocarasp. em solo no município de moreno, estado de Pernambuco, Brasil. Brazilian Journal of Veterinary Research and Animal Science, 42(5), 339-346. http://dx.doi.org/10.11606/issn.1678-4456.bjvras.2005.26410.

Lloret, A., Hartmann, K., Pennisi, M. G., Ferrer, L., Addie, D., Belák, S., Boucraut-Baralon, C., Egberink, H., Frymus, T., Gruffydd-Jones, T., Hosie, M. J., Lutz, H., Marsilio, F., Möstl, K., Radford, A. D., Thiry, E., Truyen, U., \& Horzinek, M. C. (2013). Sporotrichosis in cats: ABCD guidelines on prevention and management. Journal of Feline Medicine and Surgery, 15(7), 619-623. http://dx.doi.org/10.1177/1098612X13489225. PMid:23813827.

Loss, L. D., Mussi, J. M. S., Mello, I. N. K., Leão, M. S., \& Franque, M. P. (2012). Posse responsável e conduta de proprietários de cães no município de Alegre-ES. Acta Veterinaria Brasilica, 6, 105-111. http://dx.doi.org/10.21708/ avb.2012.6.2.2625.

Lund, E. M., Armstrong, P. J., Kirk, C. A., \& Klausner, J. S. (2006). Prevalence and risk factors for obesity in adult dogs from private US veterinary practices. International Journal of Applied Research in Veterinary Medicine, 4,177-186.

Machado, J. N., Moreira, A. B., \& Cella, P. S. (2017). Estudo das práticas criatórias decães adotadas pela comunidade do Campus dois vizinhos - UTFPR. Scientific Electronic Archives, 10, 1-5.

Magalhães, C. D. S., Lima, W. C., Lima, D. A. S. D., Quessada, A. M., Dornelles, D. E. M., \& Costa Neto, J. M. (2016). Conhecimento de tutores de cães sobre tumor de mama em cadelas. Acta Veterinaria Brasilica,10(2), 186-189. http://dx.doi.org/10.21708/avb.2016.10.2.5537.

Makloski, C. L. (2011). Canine brucellosis management. The Veterinary Clinics of North America. Small Animal Practice, 41(6), 1209-1219. http://dx.doi.org/10.1016/i.cvsm.2011.08.001. PMid:22041212.

Marlet, E. F., \& Maiorka, P. C. (2010). Análise retrospectiva de casos de maus tratos contra cães e gatos na cidade de São Paulo. Brazilian Journal of Veterinary Research and Animal Science, 47(5), 385-394. http://dx.doi. org/10.11606/issn.1678-4456.bjvras.2010.26820.

Montenegro, H., Rodrigues, A. M., Dias, A. M., Silva, E. A., Bernardi, F., \& Camargo, Z. P. (2014). Feline sporotrichosis due to Sporothrix brasiliensis: an emerging animal infection in São Paulo, Brazil. BMC Veterinary Research, 10(1), 269. http://dx.doi.org/10.1186/s12917-014-0269-5. PMid:25407096.

Nery, F. G., Borba, E. F., \& Lotufo Neto, F. (2004). Influência do estresse psicossocial no lúpus eritematoso sistêmico. Revista Brasileira de Reumatologia, 44(5), 355-361. http://dx.doi.org/10.1590/S0482-50042004000500007.

Ogoshi, R. C. S., Reis, J. S., Zangeronimo, M. G., \& Saad, F. M. O. B. (2015). Conceitos básicos sobre nutrição e alimentação de cães e gatos. Ciência Animal, 25, 64-75.

Oliveira, F., Bazan, C., Soliva, A., Ritz, R., Fagundes, E., Camargo, G., Augusto, M., Surian, C., Calderaro, T., \& Pereira, R. (2008). Criptococose. Revista Científica Eletrônica de Medicina Veterinária, 6(11).

Panegossi, M. F. C., Marques, A. E. G. W., Silveira-Neto, L., Marques, M. G., Nagata, W. B., \& Bresciani, K. D. S. (2016) Necessidade de orientação dos tutores sobre posse responsável canina. Ars Veterinária, 32(2), 88-91. http:// dx.doi.org/10.15361/2175-0106.2016v32n2p88-91.

Peruca, L. (2017). Aspectos nutricionais da alimentação úmida de cães pequenos. La Clinica Veterinaria, 22, 102. Posseti, F. S. (s/n). Controle animal: zoonoses. Umuarama: Coordenadoria de Vigilância em Saúde. Not published.

Queiroz, J. P. A. F., Sousa, F. D. N., Lage, R. A., Izael, M. A., \& Santos, A. G. (2008). Criptococose - uma revisão bibliográfica. Acta Veterinaria Brasilica, 2, 32-38. http://dx.doi.org/10.21708/avb.2008.2.2.699.

Quessada, A. M., Barbosa, E. L., Nunes, J. A. R., Oliveira, F. S., Último, A. P., \& Sugauara, Y. (2014). Perfil de proprietários de cães no município de Teresina (Brasil). Arquivos de Ciências Veterinárias e Zoologia da UNIPAR, 17, 173-175. http://dx.doi.org/10.25110/arqvet.v17i3.2014.4940.

Root Kustritz, M. V. (2012). Effects of surgical sterilization on canine and feline health and on Society. Reproduction in Domestic Animals, 47(Suppl. 4), 214-222. http://dx.doi.org/10.1111/j.1439-0531.2012.02078.x. PMid:22827373.

Rossi, L. F., Lopes, D. J., Nakasu, C. T., Guterres, K., \& Cleff, M. B. (2012). Estudo retrospectivo de atendimentos à maus tratos a animais de companhia no HCV-UFPel. Archives of Veterinary Science, 17, 31-34. 
Shiraishi, R., Nishimura, M., Nakashima, R., Enta, C., \& Hirayama, N. (2014). Neutralizing antibody response in dogs and cats inoculated with commercial inactivated rabies vaccines. Journal of Veterinary Medical Science, 76(4), 605-609. http://dx.doi.org/10.1292/ivms.13-0335. PMid:24389741.

Siddalingappa, K., Murthy, S. C., Herakal, K., \& Kusuma, M. R. (2015). Cutaneous Larva Migrans in Early Infancy. Indian Journal of Dermatology, 60(5), 522. http://dx.doi.org/10.4103/0019-5154.164436. PMid:26538729.

Silva, C. S., \& Takeda, G. K. F. (2007). Pesquisa de ovos de Toxocara canis em amostras de fezes de cães coletadas em vias públicas da cidade de São Paulo. NewsLab, 83, 130-136.

Silva, F. A. N., Carvalho, R. L., Klein, R. P., \& Quessada, A. M. (2009). Posse responsável de cães no bairro Buenos Aires na cidade de Teresina (PI). Ars Veterinária, 25, 14-17. http://dx.doi.org/10.15361/2175-0106.2009v25n1p014-017.

Silva, F. A. N., Quessada, A. M., Lima, D. A. S. D., Lima, W. C., Silva, J. D. C., \& Camapum, J. L. R. (2017). The profiles of cat and dog tutors participating in a pet neutering campaign. Acta Veterinaria Brasilica, 11(4), 184-186. http://dx.doi.org/10.21708/avb.2017.11.4.7333.

Silva, G. R., Santana, I. M., Alves, L. C., \& Faustino, M. A. G. (2014). Percepção de tutores de cães e gatos da cidade do Recife, estado de Pernambuco, Brasil, quanto aos fatores de risco à infecção por cryptosporidium spp. Acta Veterinaria Brasilica, 8, 261-267. http://dx.doi.org/10.21708/avb.2014.8.4.4785.

Silva, N. R., \& Medeiros, M. (2014). Amor e perda: a importância de acompanhar proprietários de animais terminais. MEDVEP. Revista Científica de Medicina Veterinária. Pequenos Animais e Animais de Estimação, 1, 19-30.

Soares, G. M., Souza-Dantas, L. M., D'Almeida, J. M., \& Paixão, R. L. (2010). Epidemiologia de problemas comportamentais em cães no Brasil: inquérito entre médicos veterinários. Ciência Rural, 40(4), 873-879. http://dx.doi.org/10.1590/s0103-84782010005000065.

Souza, L. C., Modolo, J. R., Padovani, C. R., Mendonça, A. O., Lopes, A. L. S., \& Silva, W. B. (2002). Posse responsável de cães no Município de Botucatu-SP: realidades e desafios. Revista de Educação Continuada CRMV-SP, 5(2), 226-232. http://dx.doi.org/10.36440/recmvz.v5i2.3277.

Stockman, J., Fascetti, A. J., Kass, P. H., \& Larsen, J. A. (2013). Evaluation of recipes of home-prepared maintenance diets for dogs. Journal of the American Veterinary Medical Association, 242(11), 1500-1505. http://dx.doi. org/10.2460/javma.242.11.1500. PMid:23683013.

Stull, J. W., Carr, A. P., Chomel, B. B., Berghaus, R. D., \& Hird, D. W. (2007). Small animal deworming protocols, client education, and veterinarian perception of zoonotic parasites in western Canada. The Canadian Veterinary Journal, 48(3), 269-276. PMid:17436903.

Tatibana, L. S., \& Costa-Val, A. P. (2009). Relação homem-animal de companhia e o papel do médico veterinário. Revista Oficial do Conselho Regional de Medicina Veterinária do Estado de Minas Gerais, 28, 12-18. http://dx.doi. org/10.1590/s0104-12902018170934.

Teixeira, J. B. D., \& Ribeiro, M. (2017). Avaliação bromatológica das principais rações secas de cães. Saber Digital, 10,105-115.

Toscano, J. H. B., Izola, B. F., Marques, N. C., Mairos, F. S., Albino, L., Paula, E. M. N., Grisolio, A. P. R., \& Carvalho, A. A. B. (2015). Percepção dos proprietários de animais de companhia sobre guarda responsável no município de Jaboticabal- sp. Ars Veterinária, 31(2), 88. http://dx.doi.org/10.15361/2175-0106.2015v31n2p88.

Vaccari, A. M. H., \& Almeida, F. A. A. (2007). Importância da visita de animais de estimação na recuperação de crianças hospitalizadas. Einstein, 5, 111-116.

Vieira, A. M. L., Almeida, A. B., Magnabosco, C., Ferreira, J. C. P., Luna, S. L. P., Carvalho, J. L. B., Gomes, L. H., Paranhos, N. T., Reichmann, M. L., Garcia, R. C., Nunes, V. F. P., \& Cabral, V. B. (2006). Programa de controle de cães e gatos do Estado de São Paulo. São Paulo. Retrieved in 2018, December 28, from http://egov.ufsc.br/ portal/sites/default/files/anexos/26764-26766-1-PB.pdf

Wang, Z., Jin, L., \& Wegrzyn, A. (2007). Leptospirosis vaccines. Microbial Cell Factories, 6(1), 39. http://dx.doi. org/10.1186/1475-2859-6-39. PMid:18072968. 